\title{
Approach to Detection of Fires in Their Very Early Stage by Odor Sensors and Neural Net
}

\author{
YOSHIAKI OKAYAMA \\ Nohmi Bosai Ltd \\ 7-3, Kudan-Minami 4-chome, Chiyoda-ku, Tokyo 102, Japan
}

\section{$A b s t r a c t$}

Two odor sensors having $\mathrm{SnO}_{2}$ fillin layers of different thickness were used for detection of different odors and their outputs were plotted on $X$ and $Y$ axes respectively. There was a clear difference between the traces of their outputs drawn as they were exposed to odors from smouldering materials and from organic solvents used everyday. So, these outputs of the sensors were given to a neural net with which a system capable of discriminating different odors was developed. This system was able to distinguish odors from smouldering materials among others with high accuracy.

Key words: fire detection, smouldering fire, odor sensor, Tin dioxide, neural net, odor recognition

\section{Introduction}

As in buildings of other occupancies, it has become difficult nowadays to detect fires in offices or factories where a variety of ventilation systems are installed and constant air flow exists by means of conventional smoke sensors [1]. In view of this and the recent report on fires in computers and electronic apparatus[2] , there is a strong demand that such fires be discovered and controlled before smoke spreads in the rooms, i.e. at the smouldering stage of fire in the electronic circuit board in the equipment. If there is an effective method of quickly finding such an abnormal environment as a sign of fire, the chances of fire outbreak would be much reduced. As flammable materials are heated gradually, they give out odors before smouldering. Therefore, it will be possible to detect fires in the very early stage if sensors are selectively perceptive to the burnt odors.

Extensive studies on discrimination of odors have been made, using odor sensors 
$[3,4,5]$. There is also a report on successful improvement of their selectivity to odors by pattern-matching method using plural sensors [6]. In 1986 Rumelhart et al proposed a neural net employing the back propagation method which is very much suited for handling analog data[7]. Moriizumi et al reported that neural net was well suited for recognition of alcohol[8]. A primitive study was also made on the use of neural nets with plural sensors to make fire judgement, which reportedly proved to be very effective for this purpose [9].

In this study two odor sensors having different $\mathrm{SnO}_{2}$ film thickness were used to investigate their responses to different odors. The output levels of each sensor were plotted on the $X$ and $Y$ axes, from which it was found that the odors given out by smouldering fires and the ones from organic compounds such as alcohol could definitely be classified into separate groups. Accordingly, a system which discriminates between those odors given out in the very beginning of fire and those existing in the normal environment was developed by using two sensors having different film thickness in conjunction with the neural nets, and its efficiency was investigated. It has been found that nearly all odors which are given out by smouldering fires and to which the odor sensors are sensitive can be regarded as odors from fires and that this system is capable of detecting the smouldering fires in their very early stage without fail.

\section{Measuring Methods}

Two sensors were built with $\mathrm{SnO}_{2}$ deposited on aluminium substrates to form film Layers of different thickness, i.e. $1000 \AA$ and $2500 \AA$ respectively, and $\mathrm{Pt}$ was spattered on their opposite sides as heaters. The sensors were heated up to $350^{\circ} \mathrm{C}$. The measuring circuit is shown in Fig.1.

\section{1 Method of Measuring Sensitivities to Burnt Odors}

Eighteen kinds of materials were prepared. They were heated at a rate of $10^{\circ} \mathrm{C} /$ min until a temperature of $350^{\circ} \mathrm{C}$ was reached, and in the mean time the sensor sensitivities to odors were measured. At the same time, smoke densities, number of particles and smoke generating temperatures were also measured, using the VESDA of I.E. I. (AUST), and the particle counter of Met One(USA). As shown in Fig.2, the measuring apparatus was equipped with a HEPA filter and deodorant filter to control the number of particles of 0.3 micron and larger in size to $10^{4}$ particles or less and to remove the odors. The materials for testing were put into a vessel in the $\mathrm{cl}^{-}$ ean duct and heated up to $330^{\circ} \mathrm{C}$. Two kinds of vessels were used for different tests. A 1.8-liter glass bell-jar was used in TEST 1 . In this test, two different sensors were placed in the bell-jar, from which air was drawn and introduced into the particle counter at a flow rate of $300 \mathrm{~mL} / \mathrm{min}$. A $65-1$ iter stainless steel box was prepared for TEST 3. At this time no sensor was placed in the box, but air drawn therefrom by pump was led into the VESDA and the sensors in the 1-liter box at a rate of $3 L / m i n$. 


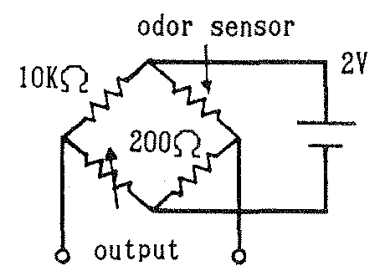

Fig. 1 Measuring circuit

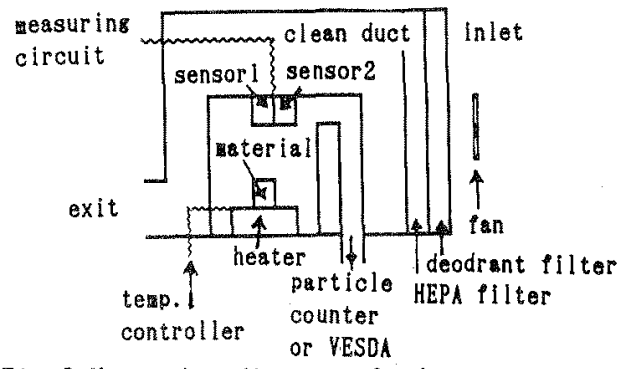

Fig. 2 Measuring diagrant of odor sensors

\section{2 Method of Measuring Sensitivi ies to Environmental Odors}

In TEST 2, two sensors were placed in the 1.8-liter bell-jar with odorant materials in sealed condition. Their sensitivities to different odors were measured as odors were generated.

\section{Result s}

\section{1 Sensitivities to odors from smouldering materials (TEST 1)}

As shown in Table 1, the sensors were highly sensitive to odors from smouldering cellulosic materials, e.g. copying paper and pine tree chip, but less sensitive to the one from cardboard. It was assumed that this slower response of the sensor in the test with the cardboard was due to lower quality paper which allowed the adhesive to dissipate as smoke at a lower temperature of $190^{\circ} \mathrm{C}$. Paper containing less impurities gave out odors and smoke at higher temperatures. Even at a temperature of $330^{\circ} \mathrm{C}$, cotton did not generate smoke but only odor. The sensors showed a high sensitivity in the test with cotton. Glass epoxy chip and paper epoxy chip used for electric circuit boards were heated to measure the sensor sensitivities. The paper epoxy chip gave out odor and smoke at $150^{\circ} \mathrm{C}$ and $180^{\circ} \mathrm{C}$ respectively. The glass epoxy chip with printed resist generated odor and smoke at $210^{\circ} \mathrm{C}$ and $300^{\circ} \mathrm{C}$ respectively.

Test results showed that the sensor was as sensitive to the odor from the glass epoxy chip as it was to the odors from the cellulosic materials while they were less sensitive to the odor from the paper epoxy chip. The sensitivities of the sensors to the odors from plastic and rubber waterials were as follows.

$$
\text { Acryl resin > Polyethylene > Polystylene > Rubber > ABS resin }
$$

It became clear from these test results that the sensors were more sensitive to the odors from the materials having a large difference between the odor generating temperature and the smoke generating temperature. Furtherwore, the sensor can sufficiently detect the odors from the cellulosic materials and the glass epoxy chip before smouldering when heated at a rate of $10^{\circ} \mathrm{C} / \mathrm{min}$.

Table 2 shows the sensor sensitivities to the burnt odors from seven different 
materials as a function of the sensor temperature.

In the tests with the copying paper, newspaper and $A B S$ resin the sensors showed increase in sensitivity but slower response time with decrease of the heater temperature. On the contrary a marked improvement was noted in the sensor sensitivity at higher heater temperature in the test with the acryl resin. In the test with the glass epoxy chip, the sensor having the film of $1000 \AA$ thick showed the same tendency as in the test with the acryl resin while the sensor having the 2500 thick film showed a maximum sensitivity at a heater temperature of $317^{\circ} \mathrm{C}$.

\section{2 Sensitivities to odors existing in normal environment (TEST 2)}

There are a great variety of odors generated in the normal environment. The materials used in this test and the sensor sensitivities to the odors measured are shown in Table 3. It was noted that the sensors showed very high sensitivities to odors given out from coffee powder and cigarette butts. It wight be natural that the sensors were very sensitive to these odors because these materials had once been roasted or burnt. The sensors also showed high sensitivities and quick response to the odors frow the materials including alcohol and volatile compounds. They were also very sensitive to odorants containing high grade alcohol. On the other hand the sensors were less sensitive to confectionary having strong flavors.

Table 1 Sensitivity and Materials (sensor was $2500 \mathrm{~A}$ thlck and heated at $350 \mathrm{C}$ )

\begin{tabular}{|c|c|c|c|c|}
\hline $\begin{array}{l}\text { Haterial } \\
\text { (heating rate } \\
\left.10^{\circ} \mathrm{C} / \mathrm{ain}\right) \\
\text { we ight: } \\
20 \mathrm{gg}\end{array}$ & $\begin{array}{l}\text { odor } \\
\text { generat- } \\
\text { ins teap } \\
{[\mathrm{C}]} \\
(\mathrm{A})\end{array}$ & $\begin{array}{l}\text { swoke } \\
\text { generat- } \\
\text { ing teap } \\
{[\text { C ] }} \\
\text { (B) }\end{array}$ & $\begin{array}{c}B-A \\
{\left[{ }^{\circ} \mathrm{C}\right]}\end{array}$ & $\begin{array}{l}\text { saoke } \\
\text { sensi- } \\
\text { tivity } \\
\text { [mV] }\end{array}$ \\
\hline Copying paper & 225 & 290 & 65 & 800 \\
\hline Newspaper & 200 & 260 & 60 & 770 \\
\hline Fil ter paper & 240 & 300 & 60 & 780 \\
\hline Cardboard & 175 & 190 & 15 & 120 \\
\hline Pine tree & 205 & 310 & 105 & 920 \\
\hline Cotton & 210 & 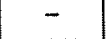 & - & 980 \\
\hline Yinyl ohrolide & 170 & 170 & 0 & 240 \\
\hline Poly ethylene & 200 & 220 & 20 & 350 \\
\hline Poly styrene & 230 & 250 & 20 & 340 \\
\hline Acryl resin & 170 & 290 & 120 & 640 \\
\hline Rubber & 140 & 170 & 30 & 170 \\
\hline Paper epoxy & 150 & 180 & 30 & 160 \\
\hline ABS resin & 150 & 180 & 40 & 100 \\
\hline Glass epoxy*1 & 210 & 300 & 90 & 850 \\
\hline Gless epoxy×z & 185 & 300 & 115 & 920 \\
\hline
\end{tabular}

*1 with resist $* 2$ without resist
Table 2 Sensitivity as a function of sensor temperature

\begin{tabular}{|c|c|c|c|c|}
\hline $\begin{array}{l}\text { Material } \\
\left(10^{\circ} \mathrm{C} / \text { min }\right)\end{array}$ & $\begin{array}{l}\text { Sensor } \\
\text { type }\end{array}$ & $\begin{array}{l}\text { Heater Teno. } \\
350^{\circ} \mathrm{C} \text { [a] }\end{array}$ & $\begin{array}{l}\text { Heater Temp. } \\
317^{\circ} \mathrm{C}[\mathrm{aV}]\end{array}$ & $\begin{array}{l}\text { Heater Teap. } \\
267^{\circ} \mathrm{C}[\mathrm{w}]\end{array}$ \\
\hline \multirow{2}{*}{$\begin{array}{l}\text { Copying } \\
\text { paper }\end{array}$} & Thin & 800 & 950 & 1000 \\
\hline & Thick & 700 & 770 & 850 \\
\hline \multirow[t]{2}{*}{ Newspaper } & Thin & 770 & 950 & 1000 \\
\hline & Thick & 450 & 900 & 960 \\
\hline \multirow{2}{*}{$\begin{array}{l}\text { Fllter } \\
\text { paper }\end{array}$} & Thin & 780 & 930 & 840 \\
\hline & Thick & 580 & 850 & 780 \\
\hline \multirow[t]{2}{*}{ ABS resin } & Thin & 100 & - & 200 \\
\hline & Thick & 70 & $\longrightarrow$ & 120 \\
\hline \multirow{2}{*}{$\begin{array}{l}\text { Acryl } \\
\text { resin }\end{array}$} & Thin & 640 & 590 & 250 \\
\hline & Thick & 900 & 860 & 600 \\
\hline \multirow{2}{*}{$\begin{array}{l}\text { Glass epoxy } \\
\text { chio } \\
\text { (no resist) }\end{array}$} & Thin & 850 & 850 & 820 \\
\hline & Thick & 720 & 760 & 720 \\
\hline \multirow{2}{*}{$\begin{array}{l}\text { Glass epoxy } \\
\text { chip } \\
\text { (resist) }\end{array}$} & Thin & 920 & 860 & 850 \\
\hline & Thick & 600 & 1000 & 650 \\
\hline
\end{tabular}


Table 3 Sensitivity to env- Table 4 Sensor sensitivity at smoke i ronmental odors (Sensor Tes. $300^{\circ} \mathrm{C}$ ) dens i t y $0.1 \% / \mathrm{m}$

\begin{tabular}{|c|c|c|c|}
\hline Materla & Quantity & $\begin{array}{l}\text { Sensor } \\
\text { type }\end{array}$ & $\begin{array}{l}\text { Sensitiz- } \\
\text { lty }[\mathrm{x} /]\end{array}$ \\
\hline \multirow{2}{*}{$\begin{array}{l}\text { Cof f e e } \\
\text { powder }\end{array}$} & \multirow{2}{*}{ 2. 0} & Thin & 1100 \\
\hline & & Thick & 1040 \\
\hline \multirow[t]{2}{*}{ Potato chip } & \multirow{2}{*}{$2 \cdot{ }_{8}^{4}$} & Thin & 0 \\
\hline & & Thick & 100 \\
\hline \multirow{2}{*}{$\begin{array}{l}\text { Cisarette } \\
\text { but }\end{array}$} & \multirow[t]{2}{*}{$5 \mathrm{~cm}$} & Thin & 1000 \\
\hline & & Thick & 840 \\
\hline \multirow[t]{2}{*}{ Perfume } & \multirow[t]{2}{*}{142} & Thin & 720 \\
\hline & & Thick & 760 \\
\hline \multirow{2}{*}{$\begin{array}{l}\text { e a d d } \\
\text { Co } 108 \pi e\end{array}$} & \multirow[t]{2}{*}{$1 \mu Q$} & Thin & 740 \\
\hline & & Thick & 800 \\
\hline \multirow{2}{*}{$\begin{array}{l}1 \text { so-propyl } \\
\text { a l cohol } \\
(I \mathrm{PA})\end{array}$} & \multirow[t]{2}{*}{$1 \mu l$} & Thin & 520 \\
\hline & & Thlck & 680 \\
\hline \multirow{2}{*}{ 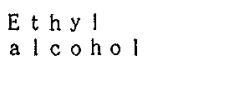 } & \multirow[t]{2}{*}{$1 \mu l$} & Thin & 720 \\
\hline & & Thick & 800 \\
\hline \multirow[t]{2}{*}{ Tol tuene } & \multirow[t]{2}{*}{$1 \mu l$} & Thin & 520 \\
\hline & & Thick & 510 \\
\hline
\end{tabular}

\begin{tabular}{|c|c|c|c|}
\hline & $A$ & $\mathrm{~B}$ & $\mathrm{~B} / \mathrm{A}$ \\
\hline$M a t e r i a \mid s$ & $\begin{array}{l}\text { Sensitivity } \\
\text { of } 1000 \AA \\
\text { sensor [iu] }\end{array}$ & $\begin{array}{l}\text { Sensitivity } \\
\text { of } 2500 \AA \\
\text { sensor [aV] }\end{array}$ & $\begin{array}{l}\text { ratio of } \\
\text { sensitivity }\end{array}$ \\
\hline Copying paper & 300 & 750 & 2. 50 \\
\hline F i l ter paper & 75 & 105 & 1. 41 \\
\hline Newspaper & 150 & 450 & 3.00 \\
\hline Pinetree & 300 & 666 & 2. 22 \\
\hline G1 ass epoxy*1 & 182 & 345 & 1. 90 \\
\hline G ass epoxy*2 & 250 & 700 & 2. 80 \\
\hline Paperepoxy & 62 & 7 & 0.11 \\
\hline Polyethylene & 57 & 178 & 3. 12 \\
\hline Cot & 1000 & 900 & 0.90 \\
\hline Acryl resin & 778 & 300 & 0.39 \\
\hline Vinylehloride & 25 & 25 & 1.00 \\
\hline ABS $r e s i n$ & 20 & 40 & 2. 00 \\
\hline $\mathrm{Cisarette*3}$ & 70 & 100 & 1. 43 \\
\hline $\begin{array}{l}\text { Materials ex } \\
\text { heated at } 35 \\
* 1 \text { with resis } \\
* 2 \text { without re } \\
* 3 \text { smoking a }\end{array}$ & 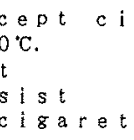 & $a r e t t e$ & were \\
\hline
\end{tabular}

(1) Copying paper

(2) Newspaper

(3) Filter paper

(4) Polyethylene

(5) Polyurethane

(6) Glass epoxy

(without resist)

(7) Glass epoxy (resist)

(8) Paper epoxy

(a) Cotton

(10) Benzyl alcohol

(11) Benzene

(2) Acryl

(13) i-octane

(14) Xylene

(15) i-propanol

(16) n-butyl alcohol

(17) Methyl ethyl ketone

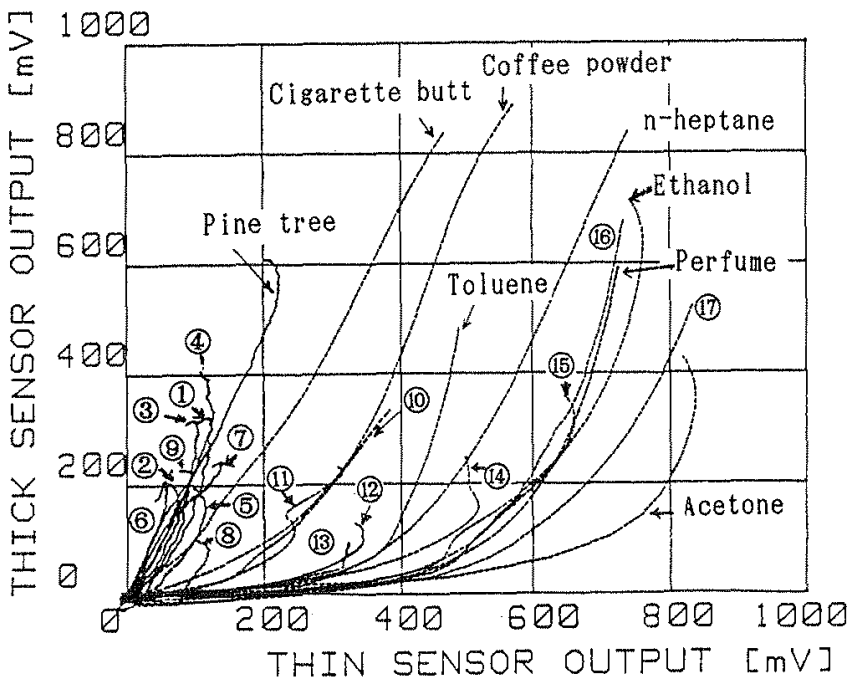

Fig. 3 Dutput traces of two sensors to various odors 


\section{3 Sensor sensitivities at smoke density of $0.1 \% /$ m (TEST 3 )}

In order to measure sensitivities of the sensors at the smoke density of $0.1 \% / \mathrm{m}$, the different materials were heated to smoulder, giving out odors and smoke in the 65-liter test box. Quantities of the materials were controlled so that a maximum smoke density of $0.15 \% /$ would not be exceeded. Table 4 shows the output changes of the sensors when subjected to the smoke density of $0.1 \% / m$ attained by swouldering of the different materials. Principal materials are listed below in the order of sensitivity shown by the sensor having the $2500 \AA$ thick filu.

\section{Cotton > Copying paper> Glass epoxy chip (without resist) > Pine tree chip >} Newspaper > Glass epoxy chip (with resist) > Acryl resin.

The sensor with its threshold level set at $300 \mathrm{mV}$, for example, is capable of giving an alarm before the smoke density of $0.1 \% / \mathrm{m}$ is reached. However, the sensors showed only slight response to odors given out while vinyl chloride or ABS resin was heated. The sensor having the film of $1000 \AA$ thick was more sensitive to the odors from the acryl resin and cotton than the sensor with the film of 2500 i thick.

\section{4 Output traces of two sensor subjected to different odors}

Outputs of the sensors with films of $1000 \AA$ and $2500 \AA$ thick were plotted on the horizontal axis and the vertical axis respectively. Fig. 3 shows the traces of their responces to the odors given out from the different smouldering materials and to organic compounds existing in the normal environment such as alcohol and perfume. In the beginning, the traces of their responses to the odors from almost all the smouldering materials concentrated in the same region in Fig.3. In contrast with this - the sensor with the $1000 \AA$ thick fila showed quick responses to the odors from ethyl alcohol,iso-propyl alcohol(IPA), toluene and perfume, and the sensor with 2500 $\AA$ thick film responded slowly thereafter, and accordingly the traces of their responses showed an upward tendency on the right side. The traces of the sensor responses to the odors from the smouldering acryl resin were similar to those attained with respect to the organic compounds. It was assumed that acryl nitrile having a low boiling point was produced due to thermal decomposition of acryl resin, and the sensor showed the same response as in the case with alcohol. The traces of the sensor responses to the odors from coffee, odorant materials and cigarette butt were located between those for the above two groups. This means that discrimination between those odors generated by fire and the ones existing in the normal environment is possible.

\section{Discrimination of Odor by Neural Net}

It was found that the traces of the sensor responses to different odors could be classified into specific groups due to kinds of odors. Therefore, a system which determines the kinds of odors was developed and evaluated, using a neural net suited for pattern matching of sensors' analog data. 
Table 5 Definition table

\begin{tabular}{|c|c|c|c|c|c|c|}
\hline \multirow[b]{2}{*}{ No } & \multicolumn{2}{|l|}{ Input } & \multicolumn{2}{|c|}{ Organic odor } & \multicolumn{2}{|c|}{ Snouldering odor } \\
\hline & $\begin{array}{l}\text { SENSOR } 1 \\
(\operatorname{thin})\end{array}$ & $\begin{array}{l}\text { SENSOR } 2 \\
\text { (thick) }\end{array}$ & $\begin{array}{l}\text { definiti- } \\
\text { on value }\end{array}$ & $\begin{array}{l}\text { calculat- } \\
\text { ed value }\end{array}$ & $\begin{array}{l}\text { definitif } \\
\text { on value }\end{array}$ & $\begin{array}{l}\text { calcuiat- } \\
\text { ed value }\end{array}$ \\
\hline 1 & 0.05 & 0.03 & 0.05 & 0.09 & 0.00 & 0.00 \\
\hline 2 & 0.05 & 0.10 & 0.05 & 0.04 & 0.10 & 0.00 \\
\hline 3 & 0.05 & 0.30 & 0.05 & 0.01 & 0.40 & 0.40 \\
\hline 4 & 0.05 & 0.50 & 0.00 & 0.01 & 0.80 & 0.87 \\
\hline 5 & 0.10 & 0.05 & 0.40 & 0.31 & 0.00 & 0.00 \\
\hline 6 & 0.10 & 0.10 & 0.20 & 0.19 & 0.00 & 0.00 \\
\hline 7 & 0.10 & 0.40 & 0.00 & 0.02 & 0.80 & 0.76 \\
\hline 8 & 0,10 & 0.70 & 0.00 & 0.01 & 0.95 & 0.94 \\
\hline 8 & 0.15 & 0.05 & 0.50 & 0.62 & 0.00 & 0.00 \\
\hline 10 & 0.20 & 0.10 & 0.70 & 0.65 & 0.00 & 0.00 \\
\hline 11 & 0.20 & 0.20 & 0.25 & 0.28 & 0.05 & 0.01 \\
\hline 12 & 0.20 & 0.40 & 0.00 & 0.04 & 0.70 & 0.69 \\
\hline 13 & 0.20 & 0.60 & 0.00 & 0.02 & 0.95 & 0.92 \\
\hline 14 & 0.40 & 0.10 & 0.95 & 0.94 & 0.00 & 0.00 \\
\hline 15 & 0.40 & 0.20 & 0.80 & 0.74 & 0.000 & 0.00 \\
\hline 18 & 0.40 & 0.30 & 0.35 & 0.35 & 0.00 & 0.00 \\
\hline 17 & 0.40 & 0.40 & 0.20 & 0.13 & 0.20 & 0.25 \\
\hline 18 & 0.40 & 0.70 & 0.00 & 0.02 & 0.95 & 0.93 \\
\hline 19 & 0.60 & 0.20 & 0.95 & 0.93 & 0.000 & 0.00 \\
\hline 20 & 0.60 & 0.40 & 0.30 & 0.36 & 0.10 & 0.01 \\
\hline 21 & 0.60 & 0.60 & 0.00 & $|0.05|$ & $0.75 \mid$ & 0.77 \\
\hline 22 & 0.80 & 0.80 & 0.00 & 0.02 & 0.95 & 0.93 \\
\hline 23 & 0.80 & 0.20 & 0.95 & 0.98 & 0.00 & 0.00 \\
\hline 24 & 0.80 & 0.40 & 0.70 & 0.71 & 0.05 & 0.00 \\
\hline 25 & 0.80 & 0.60 & 0. & 0.14 & 0.40 & 0.37 \\
\hline 26 & 0.80 & 0.80 & 0.00 & 0.03 & 0.85 & 0.9 \\
\hline
\end{tabular}

Table 6 Probability for discrimination smouldering odor and organic odor

\begin{tabular}{|c|c|c|c|}
\hline No & Kind of odor & $\begin{array}{l}\text { probability } \\
\text { of snould- } \\
\text { ering odor } \\
\text { (max. } \% \text { ) }\end{array}$ & $\begin{array}{l}\text { probability } \\
\text { of organic } \\
\text { odor } \\
\text { (max. }\end{array}$ \\
\hline 1 & Copy paper & 34.6 & 0.0 \\
\hline 2 & Pane tree & $97 \cdot 3$ & 0.0 \\
\hline 3 & Newspaper & 90.3 & 0.0 \\
\hline 4 & Filter paper & 95.9 & 0.0 \\
\hline 5 & Glass epoxy & 82.5 & 0.0 \\
\hline 6 & $n \quad(r \in s i s t)$ & 82.5 & 0.0 \\
\hline 7 & Paper epoxy & 18.4 & 0.0 \\
\hline 8 & polyurethane & 76.6 & 0.0 \\
\hline$\theta$ & Polyethylene & 96.8 & 0.0 \\
\hline 10 & Cotton & 90.9 & 0.0 \\
\hline 11 & Acry & 4.7 & 90,1 \\
\hline 12 & Collee powder & 38.2 & 26.1 \\
\hline 13 & Cisarette but & 75.6 & 1. 9 \\
\hline 14 & Ordorant & 27.2 & 26.5 \\
\hline 15 & Ethano 1 & 2. 7 & 97.6 \\
\hline 16 & $\mathrm{i}$-propanol & 2. 0 & 97.4 \\
\hline 17 & Acetone & 1.5 & 98.3 \\
\hline 18 & Benzene & 14.6 & 23.6 \\
\hline 19 & Toluene & 9. 1 & 80.0 \\
\hline 20 & $n-h$ e $p$ tane & 5.5 & 95.8 \\
\hline 21 & xylene & 2. 4 & 96.0 \\
\hline 22 & $i-o c t a n e$ & 2. 9 & 67.6 \\
\hline 23 & $n-b u t y l a \mid c 0 n \circ 1$ & 3. 6 & 97.3 \\
\hline 24 & Benzyl a lcohol & 13,2 & 43.4 \\
\hline 25 & Hethyl Ethyl Setone & 2.2 & 98,1 \\
\hline 26 & Per:ume & 2. 4 & 97.5 \\
\hline
\end{tabular}




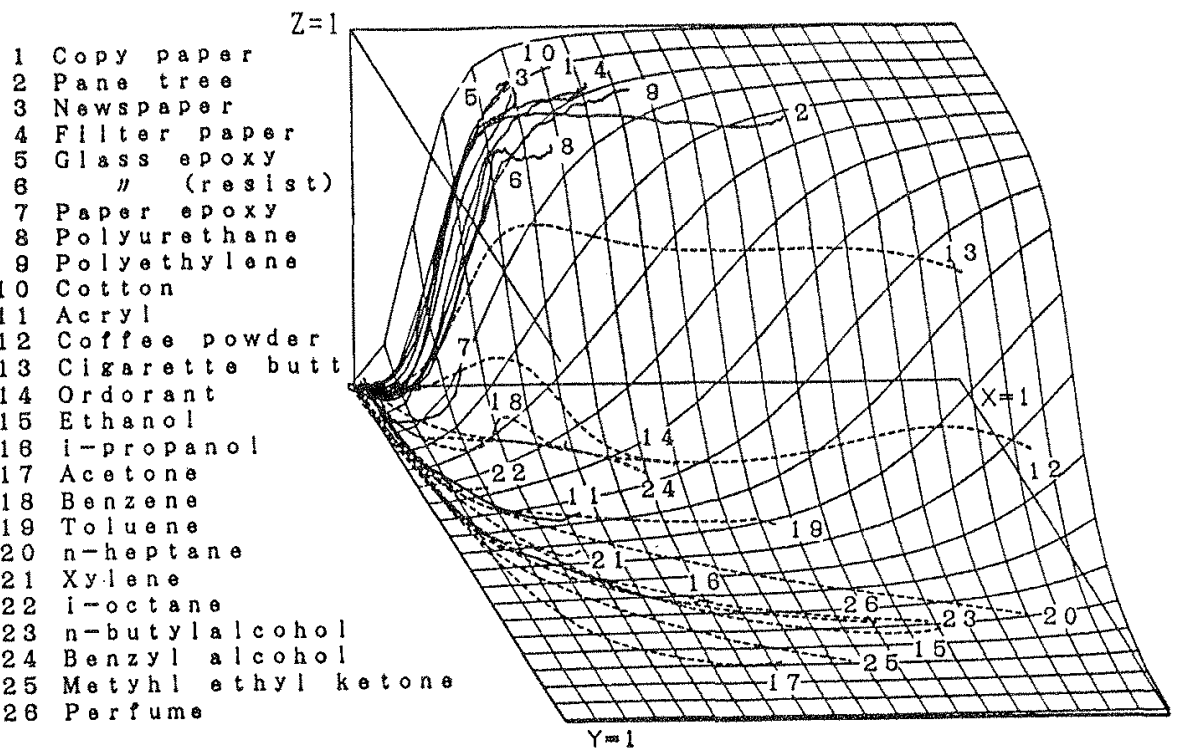

Fig. 4 Probability for smouldering odor

--- organic odor - suouldering odor

(Probability is shown with height on 2 axis.)

1 CODY papor

2 Pane tro
3 News a

4 Filter papor

5 G I a s epoxy

$6 / 1$ ( $\quad$ osist)

7 Papor opoxy

8 Polyurethane

$\theta$ Polyothylona

10 Cotton

11 A.c r y 1

12 Copfoe powder

13 Cigaretta but

14 ordorant

15 Ethanol

18 i-propanol

17 Acetono

18 Benzene

18 Toluan a

$20 n-b e p t a n \theta$

$21 X y \operatorname{lon} \theta$

$221-0 \mathrm{ctan} \theta$

23 n-butyla lcohol

24 Benzyl alcohol

$25 \mathrm{Metyhl}$ othyl ketone

26 Per in

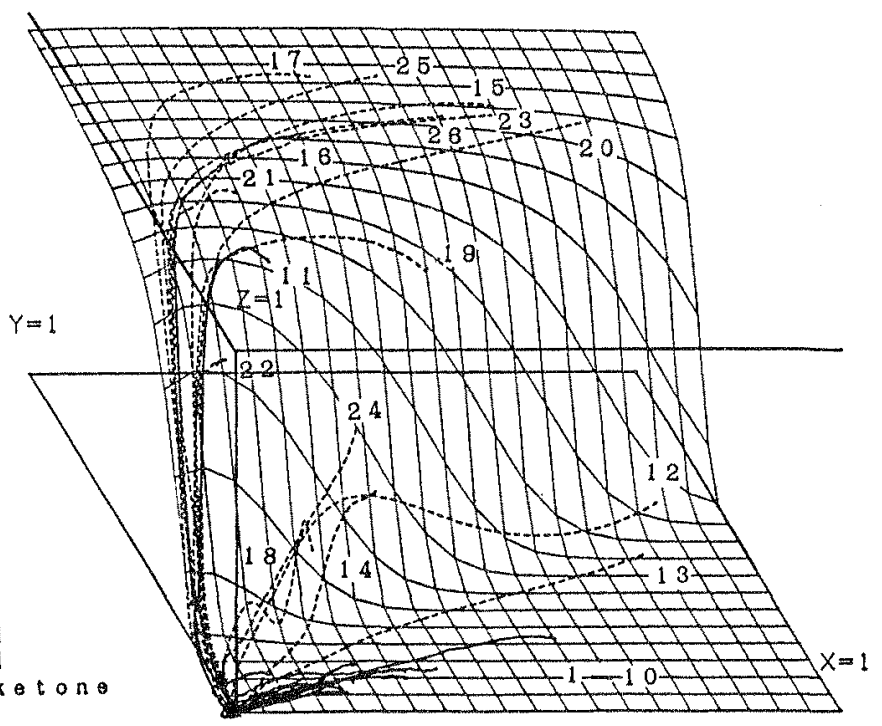

Fig. 5 Probability for organic odor

--- organic odor - suouldering odor

(Probability is shown with height on $Z$ axis.) 


\section{1 Definition of Input/Output of Neural Net}

Probability for discriminating odors from the smouldering materials and from the organic compounds as outputs was calculated by giving the outputs of the sensors having different film thickness to the neural net. The actual Definition Table has been made with reference to the traces of the sensor responses shown in Fig.3. The neural net was composed of two input neurons, five hidden neurons and two output neurons. Table 5 shows actual outputs achieved with the inputs from the sensors after the neural net learnt the Definition Table by the back-propagation method [7].

\section{2 Results of Judgement by Neural Net}

Plotting the outputs of the sensors having thin and thick film on the $X$ and $Y$ axes respectively, probability for the odors from the suouldering materials can be displayed with height on the $X$ axis as shown in Fig.4. The mesh shows the scale of defined probability. As the actual outputs of the sensors are given to the neural net for calculation, their traces can be drawn with plotted lines on the mesh. It can be seen that the neural net showed very high probability for the odors from the smouldering materials except the acryl resin. Probability for the odors from smouldering coffee and odorant materials remained with slight increase. A $75.6 \%$ of probability was attained with the odor from cigarette butt. On the other hand, the neural net showed extremely low probability, about $15 \%$ at the highest, for the group of organic compounds such as iso-propyl alcohol(IPA), ethyl alcohol, and acetone.

Likewise, probability for the odors from the organic compounds as calculated in the neural net is shown in Fig.5. The acryl resin had an exceptionally high probability and marked a maximum of $90 \%$ while the one of the other odors was zero. Table 6 shows probability for odors from different smouldering materials and organic compounds, by which difference in quality of the odors could be discriminated.

It has become apparent that affinity of odors can accurately be determined by using two odor sensors having different film thickness in conjunction with the neural net. It is also possible to distinguish difference between the odors generated in the very early stage of fire and the ones froll the organic compounds used in the normal environment without fail.

\section{Conclusion}

The investigation on sensitivities of the two odor sensors having different $\mathrm{SnO}_{2}$ film thicknesses to different odors revealed that:

(1) The sensors were highly sensitive to odors from smouldering materials including cellulose and glass epoxy chip.

(2) The film thicknesses of the sensors had a great influence upon their sensitivities. The sensor with the thicker film layer was more sensitive to the odors from the smouldering materials while the one with the thinner film 
layer was more sensitive to the odors from the organic compounds.

(3) The sensor showed increased sensitivities to the odors from the smouldering materials with the lower heater temperature, but an opposite tendency to the odors from the organic materials.

It is possible to discriminate difference in quantity between odors from the smouldering materials and organic waterials by obtaining their probability with outputs of the two sensors having different film thickness. By selectively detection the particular odors generated in the very early stage of fire by this system, it is possible to quickly and effectively smell out abnormality in the environment. If the neural net is combined with many odor sensors, it would be possible to discriminate difference between delicate odors or to identify what is smouldering more precisely. It is further expected that any abnormality in the environment be detected through odors in the future.

\section{Acknow led 8 emen}

The author would like to thank Dr. J. Unoki, President of Nohmi Bosai Ltd. for giving an opportunity to present this paper, and also thank Dr. K. Ehara of Tokyo Institute of Technology for his kind advice on this study.

\section{References}

[1] H. Ahola and M. Kokkala, "Experimental studies on detection of smouldering fires," proc. of the 9th International Conference on Automatic Fire Detection," pp.53-73, 1989 (Duisberg, FRG)

[2] "Updating the Record on Computer Center Fires," Fire Journal, March/April , pp. 31-35, 1989

[3] K. Ehara, "Odor Sensors," Sensa Gijutu (Sensor Technology) vol.9 no.2, pp.59 $-63,1989$

[4] Y. Okahara, "Sensing Odorants by Piezoelectric Crystal," Kinou Zairyo (Function Material), March, pp.38-45, 1989

[5] K. Kurihara, "Receptor Mechanism of Taste and Smell," preprint of the 37 th Spring Conference of J. Applied Physics Society, pp. 1215, March, 1990

[6] A. Ikegami, H. Arita, S. Iwanaga and M. Kaneyasu, "Thick film sensors and their integration," proc. of the 4 th European Hybrid Microelectronics Conference, pp. 211-218, 1982

[7] D.E. Rumelhart, G.E. Hint, and R.J. Hilliams, "Learning Internal Representations by Error Propagation," Parallel Distributed Processing: Exploration in the Micro structure of Cognition, yol.1: Foundation, MIT Press, 1986

[8] T. Nakamoto and H.Morilizumi, "Odor sensor using quartz-resonator array and neural network pattern recognition," proc. of the Autumn conference of Institute of Electrical Engineers of Japan,C-2, Autumn, 1988

[9] Y. Okayama, "A Primitive Study on Fire Detection Method by Artificial Neural Net," proc. of the 9th International Conference on Automatic Fire Detection, pp.409-432, 1989 (Duisberg, FRG) 